\title{
PERANCANGAN PENGAJUAN SIDANG LAPORAN PRAKTEK KERJA LAPANGAN MAHASISWA BERBASIS WEBSITE PADA SEKOLAH TINGGI ANALIS BAKTI ASIH BANDUNG
}

\author{
Tubagus Riko Rivanthio \\ Politeknik LP3I \\ email: riko_rivanthio@yahoo.com
}

\begin{abstract}
Abstrak : Penelitian ini memiliki maksud untuk merancang aplikasi pengajuan sidang Laporan Praktek Kerja Lapangan (PKL) mahasiswa Sekolah Tinggi Analis Bakti Asih. Tujuan aplikasi ini mempermudah Sekolah Tinggi Analis Bakti Asih (STABA) dalam mengelola sidang Laporan Praktek Kerja Lapangan yang telah dilakukan oleh Mahasiswa STABA. Pengelolaan yang sedang berjalan saat ini mengalami berbagai kendala, yaitu lamanya proses dalam pengajuan pemberkasan, ketidakteraturan pemberkasan di bidang akademik, penguji kesulitan dalam memperoleh draft laporan PKL sehingga tidak sedikit penguji mengeluh karena pemberian draft laporan dari akademik diberikan secara mendadak ketika sidang akan dimulai. Maka dari itu dibuatlah suatu aplikasi pengajuan sidang laporan PKL berbasis website. Aplikasi pengajuan sidang laporan PKL berbasis website ini terdiri dari, modul pengajuan sidang laporan oleh mahasiswa, modul verifikasi oleh pembimbing PKL, modul verifikasi oleh Prodi, modul Verifikasi oleh bagian akademik, modul informasi sidang PKL untuk penguji. Aplikasi pengajuan sidang laporan PKL ini diharapkan membantu Sekolah Tinggi Analis dalam mengelola sidang laporan PKL yang telah dilakukan oleh mahasiswa Sekolah Tinggi Analis Bakti Asih Bandung.
\end{abstract}

Kata Kunci : Aplikasi, Pengajuan, Online, Sidang, Laporan, Praktek Kerja Lapangan

\section{Pendahuluan}

Sekolah Tinggi Analis Bakti Asih Bandung yang disingkat menjadi STABA, merupakan salah satu perguruan tinggi analis yang ada di Bandung. STABA memiliki dua program studi yang terdiri dari S1 Analis Kimia dan D3 Analis Kesehatan. Salah satu misi dari STABA adalah menyelenggarakan pendidikan analis secara profesional sesuai dengan perkembangan ilmu pengetahuan dan teknologi dengan menghasilkan tenaga terdidik yang bertaqwa kepada Tuhan Yang Maha Esa, berakhlak mulia, berbudaya Indonesia, professional dan memiliki daya saing global.

Dalam mencapai salah satu misi tersebut Sekolah Tinggi Analis Bakti Asih Bandung, memiliki struktur kurikulum yang dapat mendukung lulusan sekolah Tinggi Analis Bakti Asih sesuai dengan misi yang diharapkan oleh Sekolah Tinggi Analis Bakti Asih. Salah satu dari struktur kurikulum yang dapat mendukung lulusan Sekolah Tinggi Analis Bakti Asih adalah adanya mata kuliah Praktek Kerja Lapangan.

Mata kuliah Praktek Kerja Lapangan adalah mata kuliah yang harus ditempuh oleh mahasiswa Sekolah Tinggi Analis Bakti Asih sebelum melakukan Skripsi. Praktek Kerja Lapangan yang dilakukan oleh mahasiswa dilaksanakan dalam waktu 3 bulan. Tempat Praktek Kerja Lapangan mahasiswa STABA bertempat diberbagai instansi kesahatan dan perusahaan, seperti labotarium kesehatan rumah sakit, dibagian quality control perusahaan makanan dan minuman. Praktek Kerja Lapangan yang dilakukan oleh 
mahasiswa boleh dilaksanakan berkelompok atau perseorangan. Setiap kelompok akan dibimbing oleh Pembimbing PKL yang ditunjuk oleh pihak Sekolah Tinggi Analis Bakti Asih.

Mahasiswa yang telah menyelesaikan praktek kerja lapangan diwajibkan membuat laporan praktek kerja lapangan, dimana laporan tersebut adalah bukti kegiatan-kegiatan yang telah dilakukan oleh mahasiswa di tempat praktek kerja lapangan. Laporan PKL dibuat secara kelompok sesuai dengan kelompok tempat PKL mahasiswa. Laporan PKL yang telah dibuat oleh mahasiswa wajib dipresentasikan dan dipertanggungjawabkan kepada dosen penguji yang telah ditunjuk oleh pihak Sekolah Tinggi Analis Bakti Asih yaitu oleh bagian Program Studi. Laporan PKL wajib disetujui oleh Pembimbing PKL sebelum dipresentasikan kepada dosen penguji.

Pada sistem yang berjalan setelah mahasiswa membuat laporan PKL yang telah disetujui oleh Pembimbing PKL. Mahasiswa diwajibkan mengajukan tanggal sidang laporan PKL kepada akademik dan akan dicek kelengkapan persyaratan untuk sidang laporan PKL. Setelah persyaratan laporan PKL terpenuhi, maka bagian akademik akan meneruskan kepada bagian program studi untuk melakukan verifikasi tanggal sidang yang diajukan dan menentukan penguji sidang laporan PKL mahasiswa. Setelah bagian program studi melakukan verifikasi dan menentukan penguji, maka bagian akademik akan melakukan pemberitahuan kepada mahasiswa, pembimbing dan penguji tentang waktu dan tempat sidang laporan PKL.

Kendala yang dihadapi pada sistem yang berjalan adalah lamanya proses pengajuan karena kepala program studi tidak selalu ditempat, penumpukan draft laporan yang diajukan oleh mahasiswa sehingga terjadinya ketidakteraturan dibagian akademik, keterambatan pengumpulan draft laporan oleh mahasiswa dan kesulitan dalam menemui dosen penguji karena tidak selalu ditempat menjadi kendala dalam proses pemberian draft laporan kepada penguji.

Solusi untuk mengatasi kendala yang dihadapi oleh sistem yang berjalan adalah dibuatnya suatu aplikasi pengajuan sidang laporan PKL secara online yaitu berbasis website. Adanya web aplikasi pengajuan sidang laporan PKL dapat mempermudah pihak Sekolah Tinggi Analis Bakti Asih dalam mengelola sidang laporan PKL mahasiswa. Mahasiswa dengan mudah dan cepat dalam mengajukan waktu sudang dan draft laporan kepada akademik. Bagian Akademik dimudahkan dalam mengelola draft laporan PKL dan mengecek persyaratan sidang laporan PKL. Pembimbing PKL dengan mudah melakukan verifikasi waktu dan draft yang diajukan oleh mahasiswa bimbingannya. Kepala Program Studi dengan mudah melakukan verifikasi waktu dan menentukan penguji untuk sidang laporan PKL yang telah diajukan oleh mahasiswa kapanpun dan dimanapun posisi Kepala Program Studi berada. Penguji dengan mudah memperoleh draft laporan PKL mahasiswa yang akan diuji, sehingga penguji dapat mempelajari laporan PKL mahasiswa dengan baik.

Modul yang akan dirancang pada aplikasi pengajuan sidang laporan PKL terdiri dari, modul pengajuan sidang laporan oleh mahasiswa, modul verifikasi oleh pembimbing PKL, modul verifikasi oleh Prodi, modul Verifikasi oleh bagian akademik, modul informasi sidang PKL untuk penguji yaitu informasi waktu, tempat dan melihat draft laporan PKL mahasiswa yang akan diuji. 
Perancangan aplikasi ini menggunakan metode waterfall. Menurut Sukamto (2015), model waterfall menggunakan pendekatan alur hidup perangkat lunak secara sekuensial, yaitu dimulai dari analis, desain, pengkodean, dan pengujian. Aplikasi pengajuan sidang laporan PKL mahasiswa ini diharapkan membantu Sekolah Tinggi Analis dalam mengelola sidang laporan PKL yang telah dilakukan oleh mahasiswa Sekolah Tinggi Analis Bakti Asih Bandung.

\section{Landasan Teori}

\subsection{Pengertian Perancangan Aplikasi}

Menurut Presman dalam Syukroni (2017), Perancangan merupakan dasar utama dalam membuat aplikasi, dengan tujuan memberikan gambaran lengkap dengan jelas kepada programmer tentang aplikasi yang akan dibuat. perancangan atau rancang merupakan serangkaian prosedur untuk menerjemahkan hasil analisa dan sebuah sistem ke dalam bahasa pemrograman untuk mendeskripsikan dengan detail bagaimana komponen-komponen sistem diimplementasikan.

Definisi lainnya adalah menurut Sujatmiko (2012:259) “Application merupakan program komputer yang dibuat oleh suatu perusahaan komputer untuk membantu manusia dalam mengerjakan tugas-tugas tertentu".

Dari kedua pengertian tersebut, dapat disimpulkan bahwa pengertian Aplikasi adalah program komputer yang didesain oleh suatu perusahaan komputer untuk di pakai oleh userdalam mengerjakan tugas-tugas tertentu.

\subsection{Pengertian Website}

Bekti (2015:35), "Website merupakan kumpulan halaman-halaman yang digunakan untuk menampilkan informasi teks, gambar diam atau gerak, animasi, suara, dan atau gabungan dari semuanya, baik yang bersifat statis maupun dinamis yang membentuk satu rangkaian bangunan yang saling terkait, yang masing-masing masing dihubungkan dengan jaringan-jaringan halaman".

\subsection{Pengertian Waterfall}

Menurut Sukamto dan Shalahuddin (2015:28) "Model air terjun menyediakan pendekatan alur hidup perangkat lunak secara sekuensial atau terurut dimulai dari analisis, desain, pengkodean, pengujian dan tahap pendukung (support)".

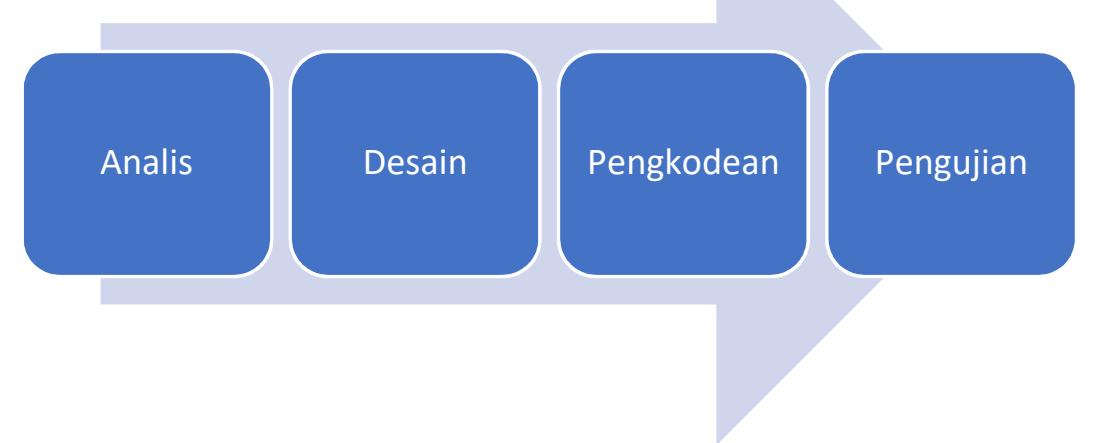

Gambar 1. Model Waterfall

\section{Metode Penelitian}

Pada penelitian ini digunakan metode waterfall yang terdiri dari :

a. Analisis 
Pada tahap analisis adalah tahap untuk mengidentifikasi kebutuhan yang diperlukan sesuai dengan masalah yang terjadi, yaitu :

1) Modul

a) Modul Pengajuan Laporan PKL oleh Mahasiswa

Modul untuk mahasiswa mengajukan sidang laporan PKL, diamana data yang diinput adalah data mahasiswa dan kelompok mahasiswa, waktu sidang yang diajukan, mengunggah draft, slide presentasi, dokumen-dokumen persyaratan untuk sidang PKL

b) Modul Verifikasi Pembimbing PKL

Modul ini digunakan oleh pembimbing PKL untuk melakukan verifikasi pengajuan sidang laporan PKL yang dilakukan mahasiswa bimbinganya. Selain melakukan verifikasi pembimbingpun dapat melakukan penilaian terhadap mahasiswa bimbingannya.

c) Modul Verifikasi Program Studi

Modul untuk melihat data pengajuan sidang laporan PKL mahasiswa yang telah disetujui oleh Pembimbing PKL. Pada modul ini program studi dapat melakukan verifikasi jadwal sidang dan menentukan penguji sidang.

d) Modul Akademik

Modul digunakan untuk akademik dalam melakukan verifikasi dokumen-dokumen pesyaratan sidang laporan PKL, dan untuk menentukan tempat sidang laporan PKL

e) Modul Penguji

Modul digunakan untuk penguji dalam melihat data sidang yang akan diuji oleh penguji. Pada modul inipun penguji dapat memberikan nilai hasil sidang laporan PKL yang dilakukan oleh mahasiswa.

2) User

a) Akademik

b) Mahasiswa

c) Pembimbing PKL

d) Program Studi

e) Penguji

3) Media

a) Website online

b) Hosting dan domain

b. Desain

Pada desain perancangan sistem digunakan model UML yang terdiri dari :

1) Activity Diagram

Activity Diagram digunakan untuk menggambarkan aktivitas yang terjadi pada proses pengajuan sidang laporan PKL mahasiswa Sekolah Tinggi Analis Bakti Asih, adapun activity diagramnya adalah sebagai berikut : 


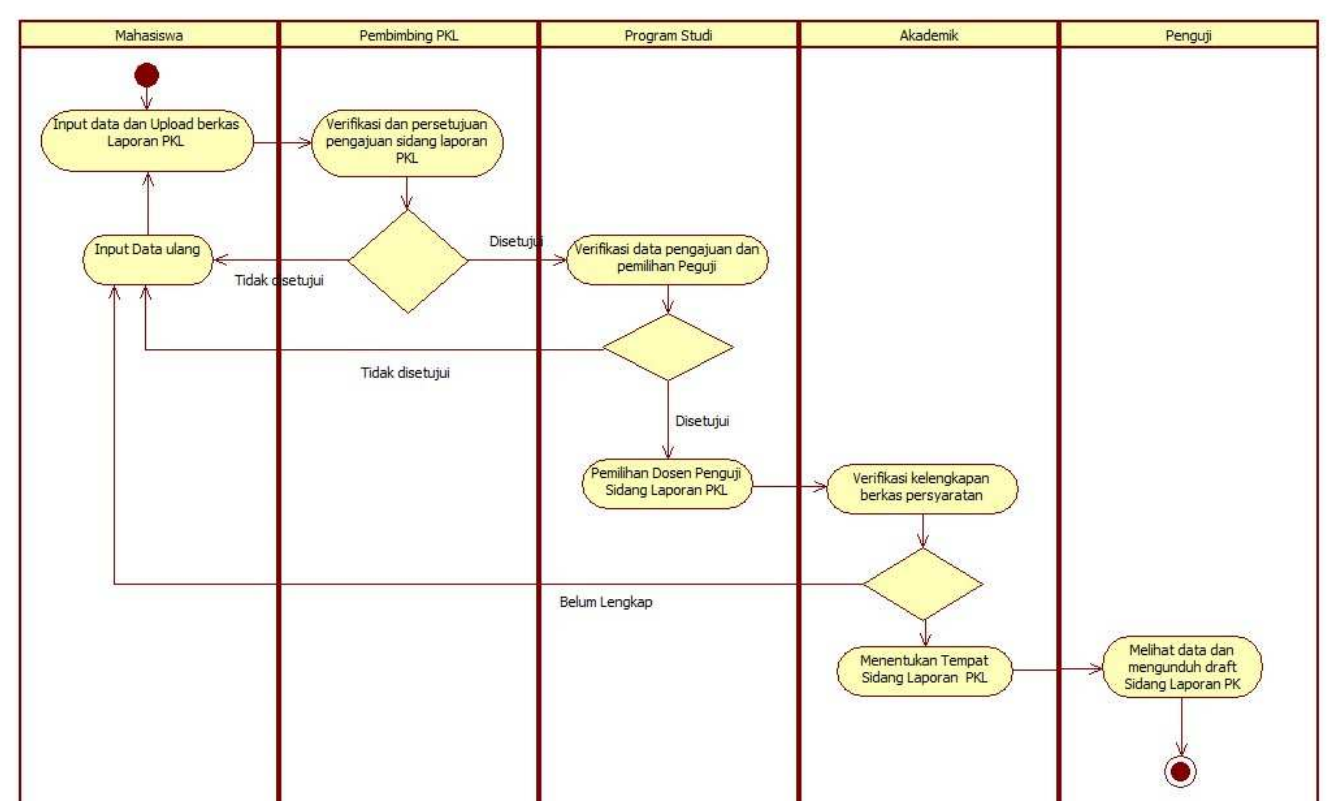

Gambar 2. Aktivitas Pengajuan Sidang Laporan PKL

2) Usecase Diagram

Use Case Diagram digunakan untuk menggambarkan interaksi antara sistem atau aplikasi yang akan dibuat dengan user yang mengakses aplikasi tersebut. Dimana pada use case diagram akan digambarkan bagaimana setiap modul saling berkaitan satu sama lainnya, yang terdiri dari modul pengajuan mahasiswa, modul verifikasi dosen pembimbing beserta input nilai dan berita acara sidang, modul verifikasi program studi, modul verifikasi akademik, modul penguji berserta input nilai. Adapun use case diagram aplikasi pengajuan sidang laporan PKL mahasiswa Sekolah Tinggi Analis Bakti asih adalah sebagai berikut :

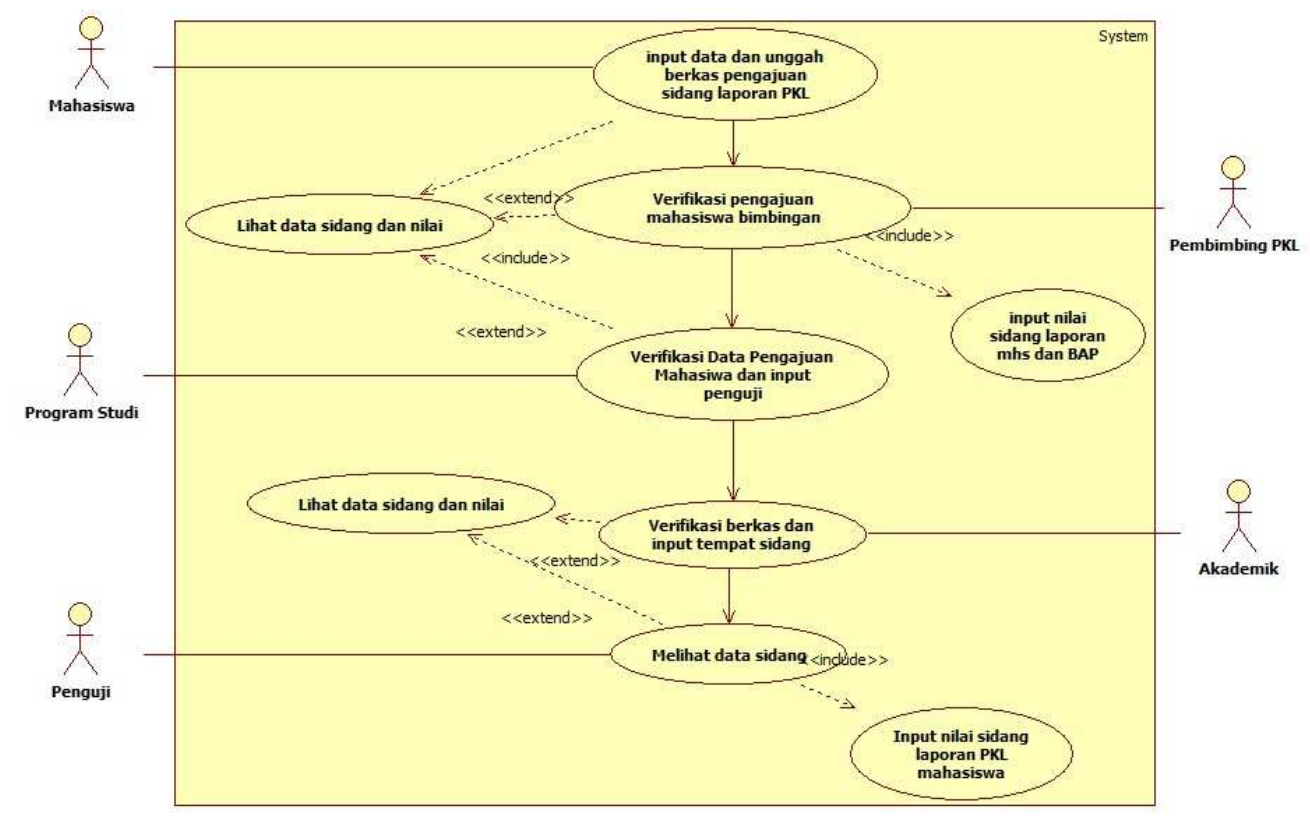

Gambar 2. Use Case Diagram Aplikasi Pengajuan Sidang Laporan PKL 
3) Use Case Scenario

Use Case Scenario adalah tabel untuk menggambarkan secara detail proses pada setiap use case yang telah dibuat.

Nama Use Case : Input data dan unggah berkas

Aktor : Mahasiswa

\begin{tabular}{|l|l|}
\hline \multicolumn{1}{|c|}{ Aksi Aktor } & \multicolumn{1}{c|}{ Reaksi Sistem } \\
\hline $\begin{array}{l}\text { 1. Input data pengajuan sidang } \\
\text { dan berkas laporan PKL }\end{array}$ & $\begin{array}{l}\text { 2. Menyimpan data pengajuan dan } \\
\text { berkas laporan PKL } \\
\text { 3. Menampilkan data hasil } \\
\text { penginputan data }\end{array}$ \\
\hline
\end{tabular}

Nama Use Case : Verifikasi Pengajuan Mahasiswa Bimbingan

Aktor : Pembimbing PKL

\begin{tabular}{|l|rl|}
\hline \multicolumn{2}{|c|}{ Aksi Aktor } & \multicolumn{1}{c|}{ Reaksi Sistem } \\
\hline $\begin{array}{l}\text { 1. Klik data pengajuan } \\
\text { mahasiswa }\end{array}$ & 2. Menampilkan data pengajuan \\
\hline 3. Klik tombol verifikasi & 4. $\begin{array}{l}\text { Memasukkan data kedalam } \\
\text { database } \\
\end{array}$ & $\begin{array}{l}\text { 5. Menampilkan konfirmasi } \\
\text { berhasil diverifikasi }\end{array}$ \\
& 6. $\begin{array}{l}\text { Menampilkan data pengajuan } \\
\text { sidang yang telah diverifikasi }\end{array}$ \\
\hline
\end{tabular}

Nama Use Case : Verifikasi data pengajuan dan input penguji

Aktor : Program Studi

\begin{tabular}{|c|c|}
\hline Aksi Aktor & Reaksi Sistem \\
\hline $\begin{array}{l}\text { 1. Klik data pengajuan data } \\
\text { sidang laporan PKL }\end{array}$ & 2. Menampilkan data pengajuan \\
\hline $\begin{array}{l}\text { 3. Melakukan verifikasi dan } \\
\text { input data penguji }\end{array}$ & $\begin{array}{l}\text { 4. Memasukkan data konfirmasi } \\
\text { ke dalam database } \\
\text { 5. Menampilkan konfirmasi } \\
\text { berhasil diverifikasi } \\
\text { 6. Menampilkan data pengajuan } \\
\text { sidang yang telah diverifikasi }\end{array}$ \\
\hline
\end{tabular}

Nama Use Case : Verifikasi berkas dan input tempat sidang PKL

Aktor : Akademik

\begin{tabular}{|c|c|}
\hline Aksi Aktor & Reaksi Sistem \\
\hline $\begin{array}{l}\text { 1. Klik data pengajuan data } \\
\text { sidang laporan PKL }\end{array}$ & 2. Menampilkan data pengajuan \\
\hline $\begin{array}{l}\text { 3. Melakukan verifikasi berikas } \\
\text { dan input data tempat sidang }\end{array}$ & $\begin{array}{l}\text { 4. Memasukkan data konfirmasi } \\
\text { ke dalam database } \\
\text { 5. Menampilkan konfirmasi } \\
\text { berhasil diverifikasi } \\
\text { 6. Menampilkan data pengajuan } \\
\text { sidang yang telah diverifikasi }\end{array}$ \\
\hline
\end{tabular}


Nama Use Case : Melihat data sidang

Aktor : Penguji

\begin{tabular}{|c|c|}
\hline Aksi Aktor & Reaksi Sistem \\
\hline $\begin{array}{l}\text { 1. Klik data pengajuan data } \\
\text { sidang laporan PKL }\end{array}$ & $\begin{array}{l}\text { 2. Menampilkan data sidang } \\
\text { laporan PKL } \\
\text { 3. Mengunduh draft laporan PKL }\end{array}$ \\
\hline
\end{tabular}

4) Class Diagram

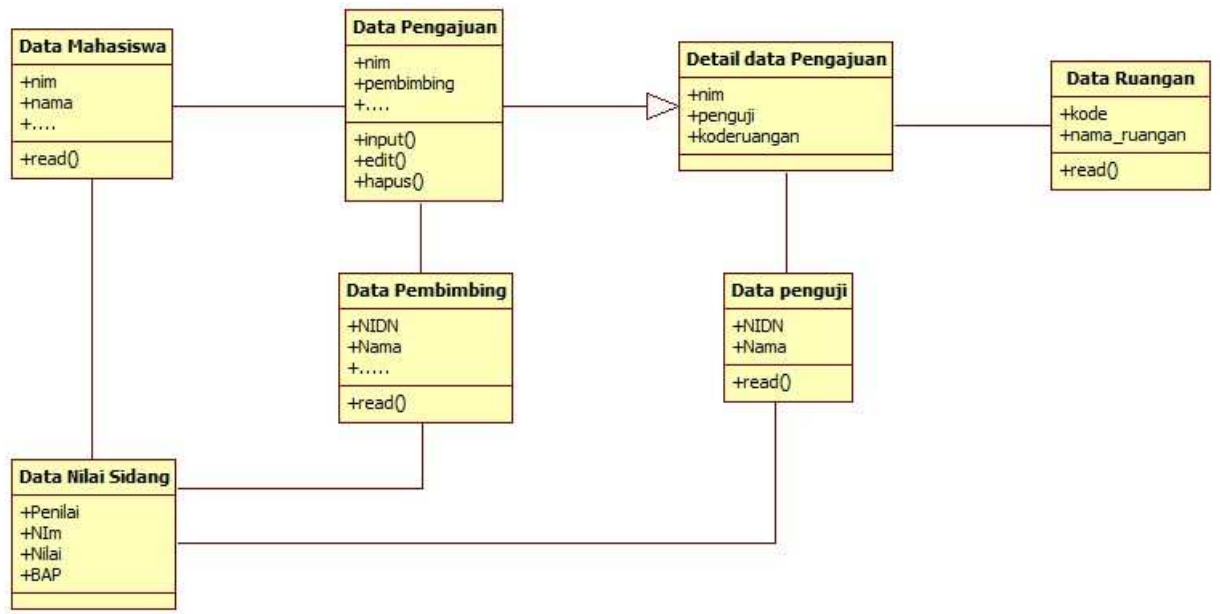

Gambar 4. Class Diagram Aplikasi Pengajuan Sidang Laporan PKL

\section{Implementasi}

Langkah selanjutnya adalah melakukan pengkodean untuk pembuatan web, adapun tools yang digunakan dalam pembuatan website pelayanan online pada Master Clean adalah sebagai berikut :
1) Database : Mysql
2) Kode Fungsi : $\quad$ PHP
3) Kode Tampilan : HTML, CSS Bootstrap
4) Kode Even : Javacript

Sedangkan hasil tampilan adalah sebagai berikut :

1) Halaman Utama

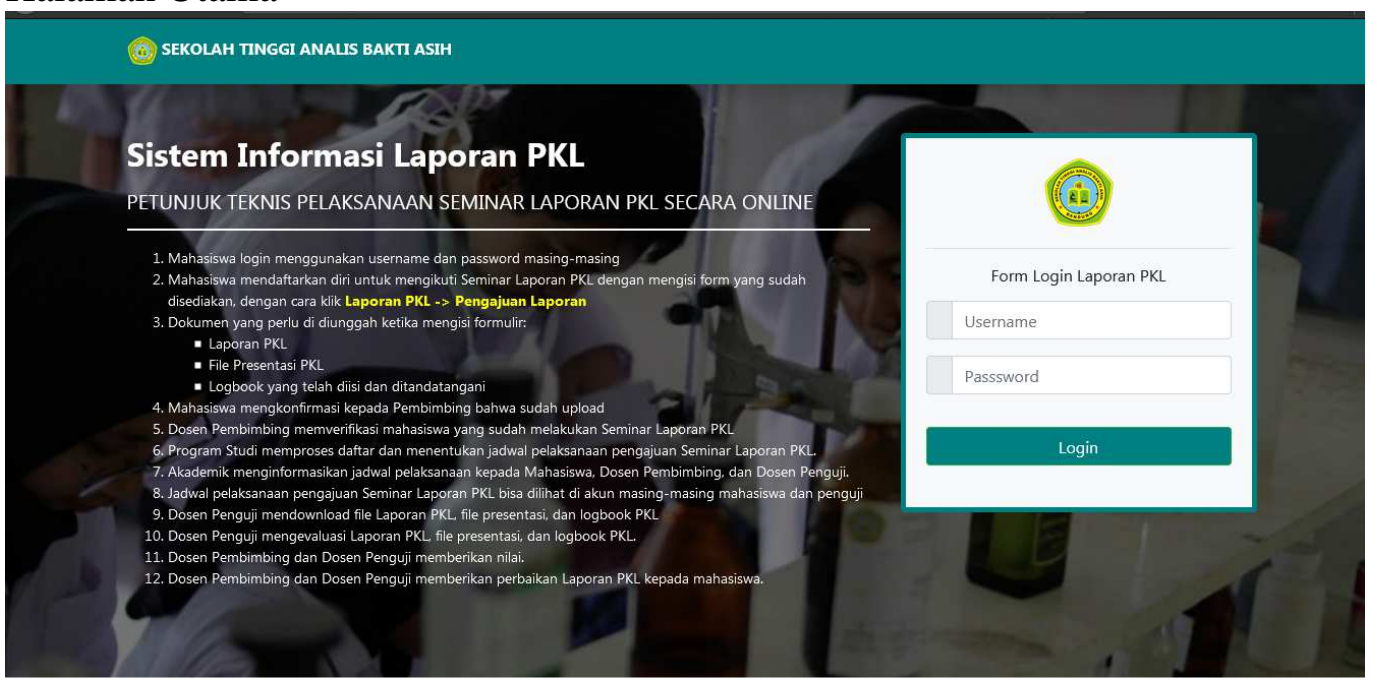


2) Halaman Informasi prosedur pengajuan untuk mahasiswa
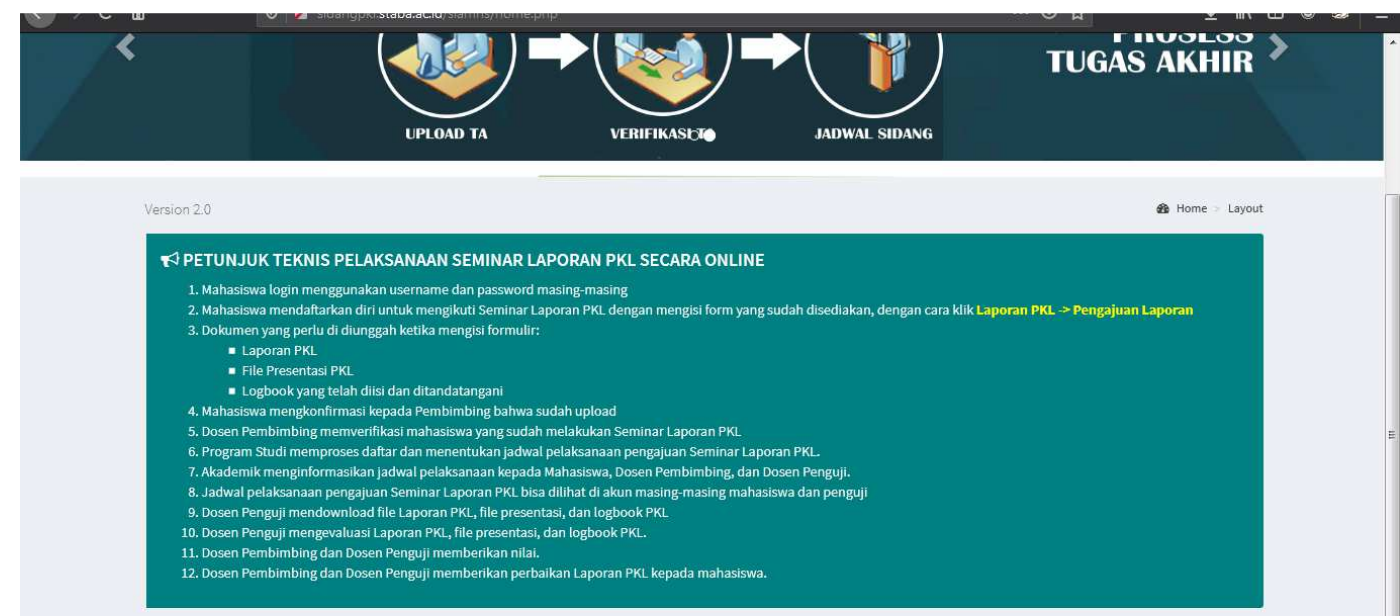

Copyright @ 2020-2021 || built with | ICT.STABA Bandung.

Version 2.4 .0

3) Halaman pengajuan sidang laporan PKL mahasiswa

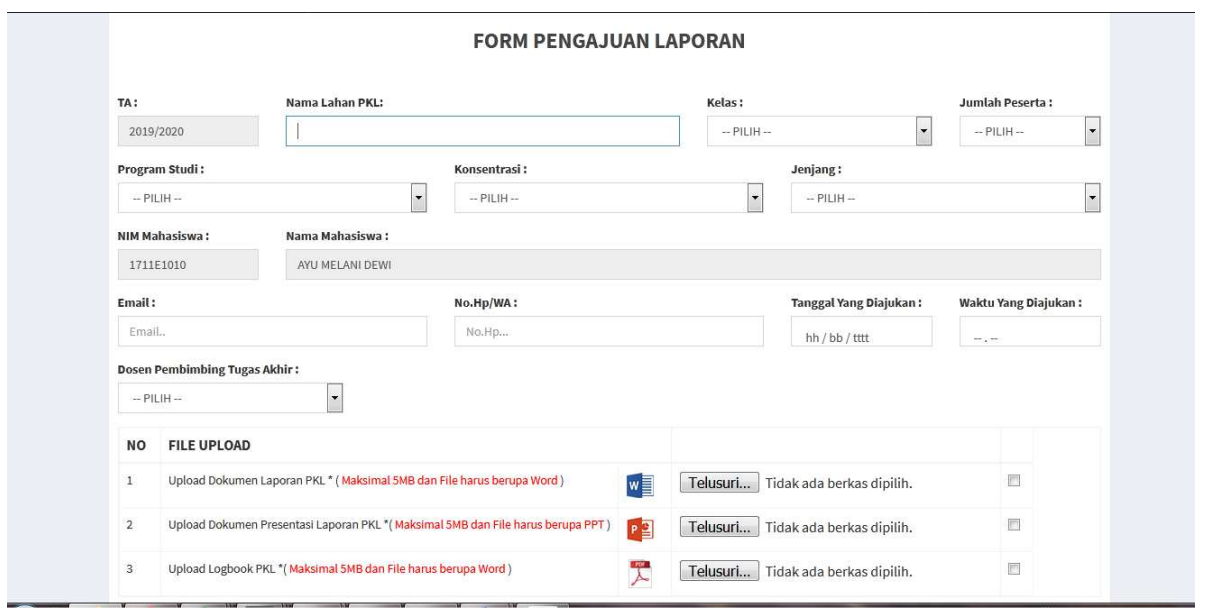

4) Halaman Verifikasi persetujuan oleh pembimbing

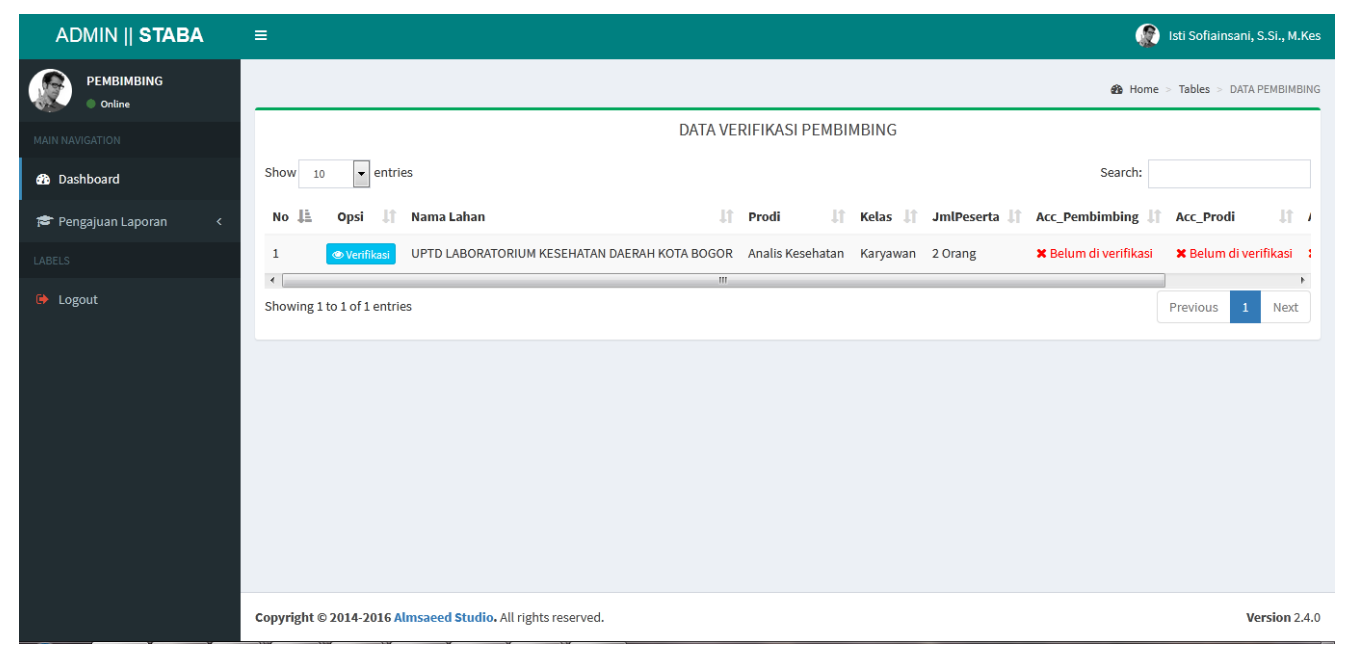


5) Halaman input nilai oleh pembimbing

\begin{tabular}{|c|c|c|c|c|c|}
\hline ADMIN \| STABA & \multicolumn{4}{|l|}{$\equiv$} & Q isti sofiainsani, S.Sil, M.Kes \\
\hline 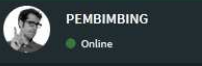 & \multicolumn{4}{|c|}{ Tugas Akhir } & - Home Pengajuan Laporan \\
\hline Dashboard & \multirow{2}{*}{\multicolumn{5}{|c|}{$\begin{array}{l}\text { LEMBAR PENILAIAN UJIAN PRAKTEK KERJA LAPANGAN (PKL) } \\
\text { Tahun Akademik: 2019/2020 }\end{array}$}} \\
\hline F Pengajuan Laporan & & & & & \\
\hline uagels & \multirow{2}{*}{\multicolumn{5}{|c|}{ 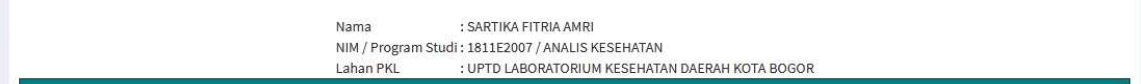 }} \\
\hline \multirow{8}{*}{ at logout } & & & & & \\
\hline & \multicolumn{5}{|c|}{ A. ASPEK MANAJEMEN } \\
\hline & No & ASPEK YANG DINILAI & NLLA MaX & NILAI & КЕт \\
\hline & 1 & Alur Kerja dan Hubungan Personel & 5 & 뇐 & \\
\hline & 2 & Sampel dan penanganannya,dan dokumen samp & 10 & $\Leftrightarrow$ & \\
\hline & 3 & Distirbusis sampel dan dokumen & 5 & 숴 & \\
\hline & \multicolumn{5}{|c|}{ B. TEKNIK LABORATORIUM } \\
\hline & No & ASPEK YANG DINILAI & NLLA MaX & NILAI & КЕт \\
\hline
\end{tabular}

6) Halaman Berita Acara Persidangan oleh pembimbing PKL

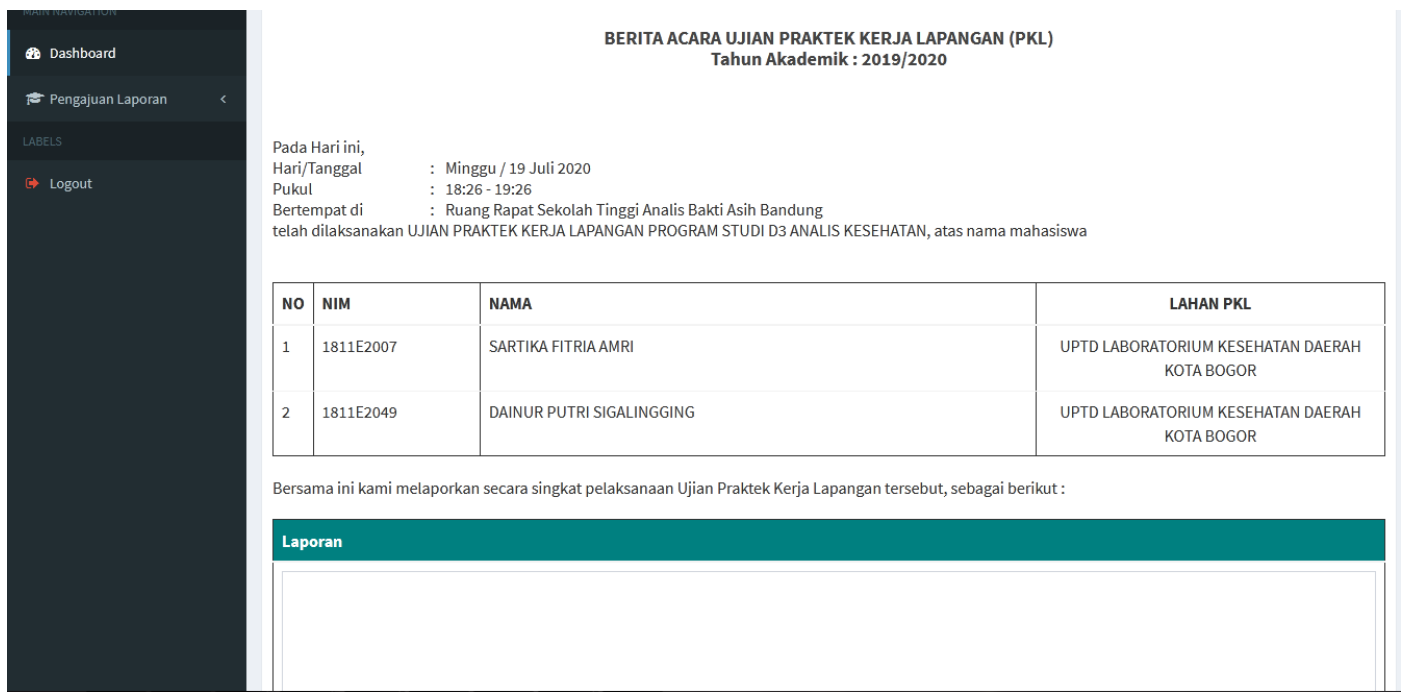

7) Halaman Verifikasi oleh Program Studi

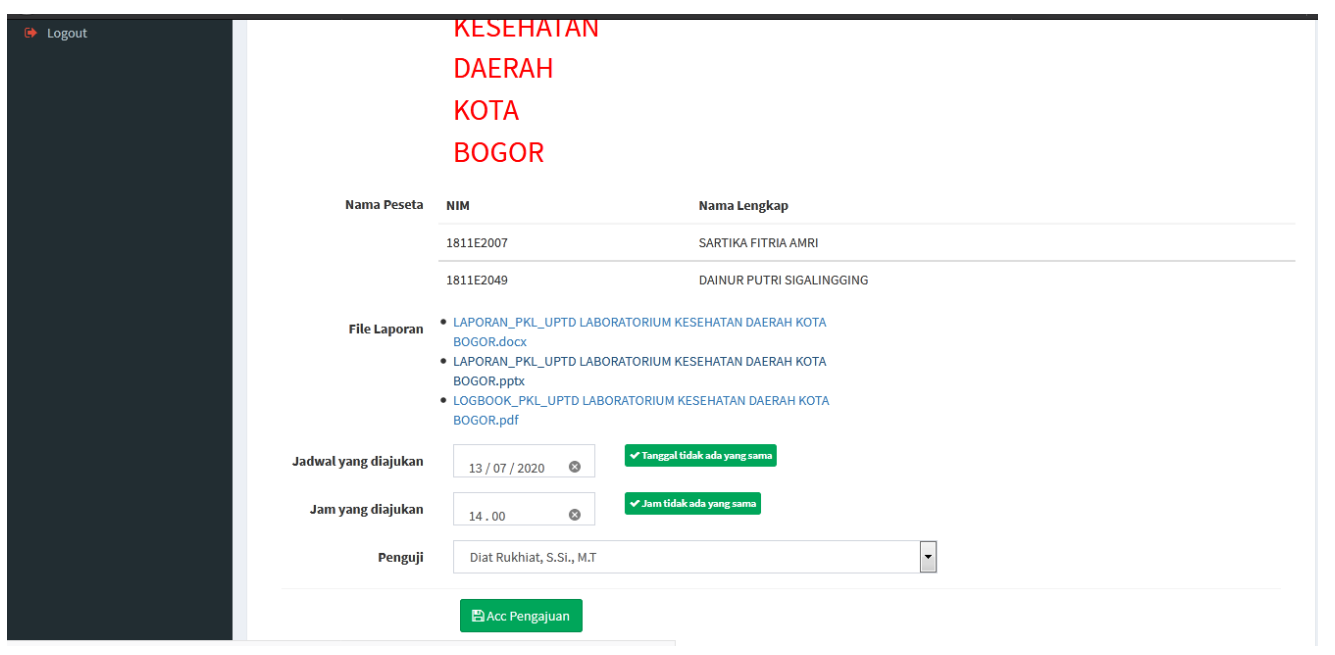


8) Halaman Verifikasi oleh akademik

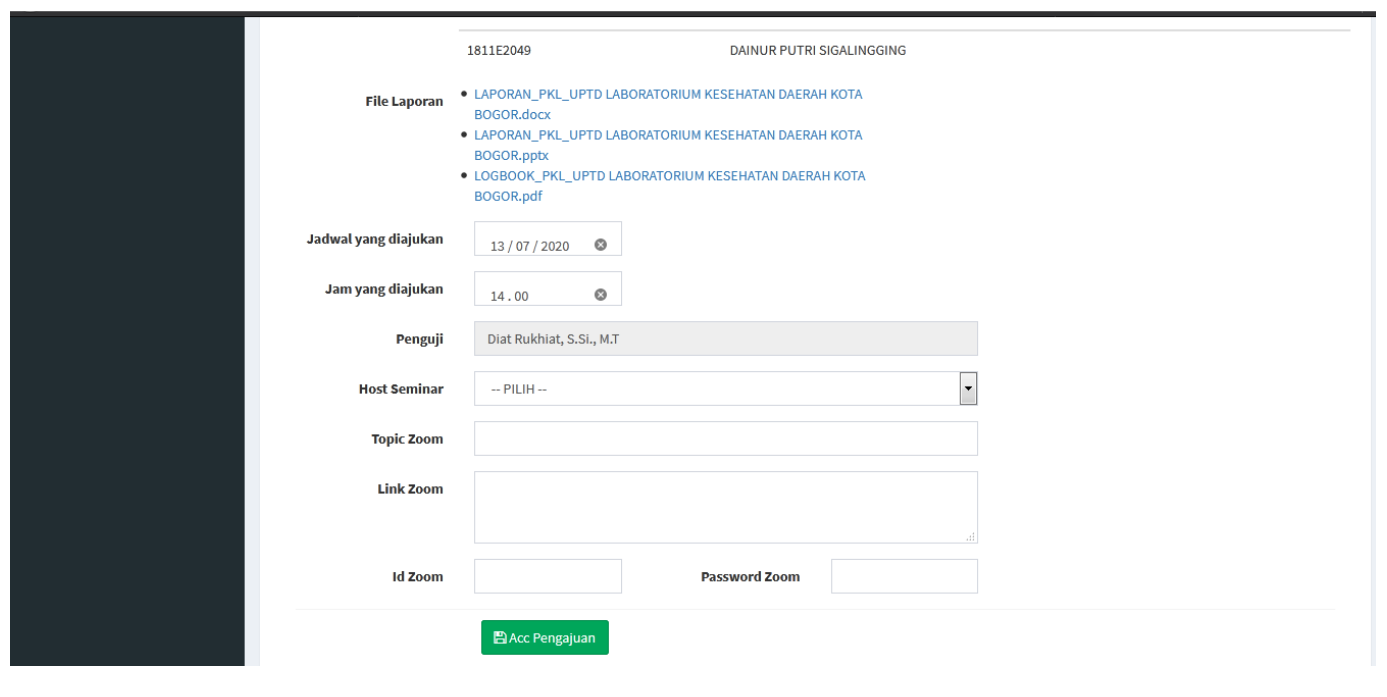

9) Halaman penguji

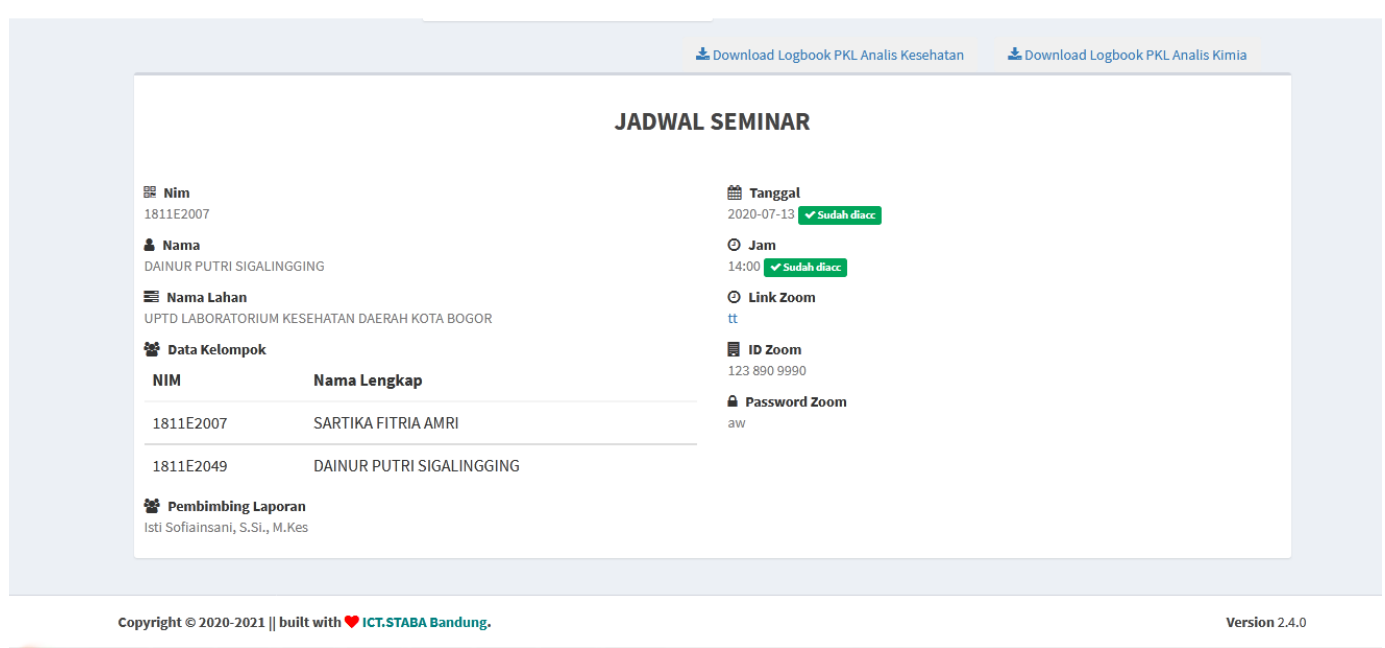

c. Pengujian

Pengujian Aplikasi menggunakan pengujian blackbox

\begin{tabular}{|l|l|l|l|}
\hline No & Skenario Pengujian & Hasil yang dharapkan & $\begin{array}{l}\text { Kesimpu } \\
\text { lan }\end{array}$ \\
\hline 1 & $\begin{array}{l}\text { a. Klik Pengajuan Laporan } \\
\text { b. Klik Verifikasi Laporan } \\
\text { c. Klik Jadwal Laporan }\end{array}$ & a. Tampil halaman pengajuan Laporan & Valid \\
\hline
\end{tabular}




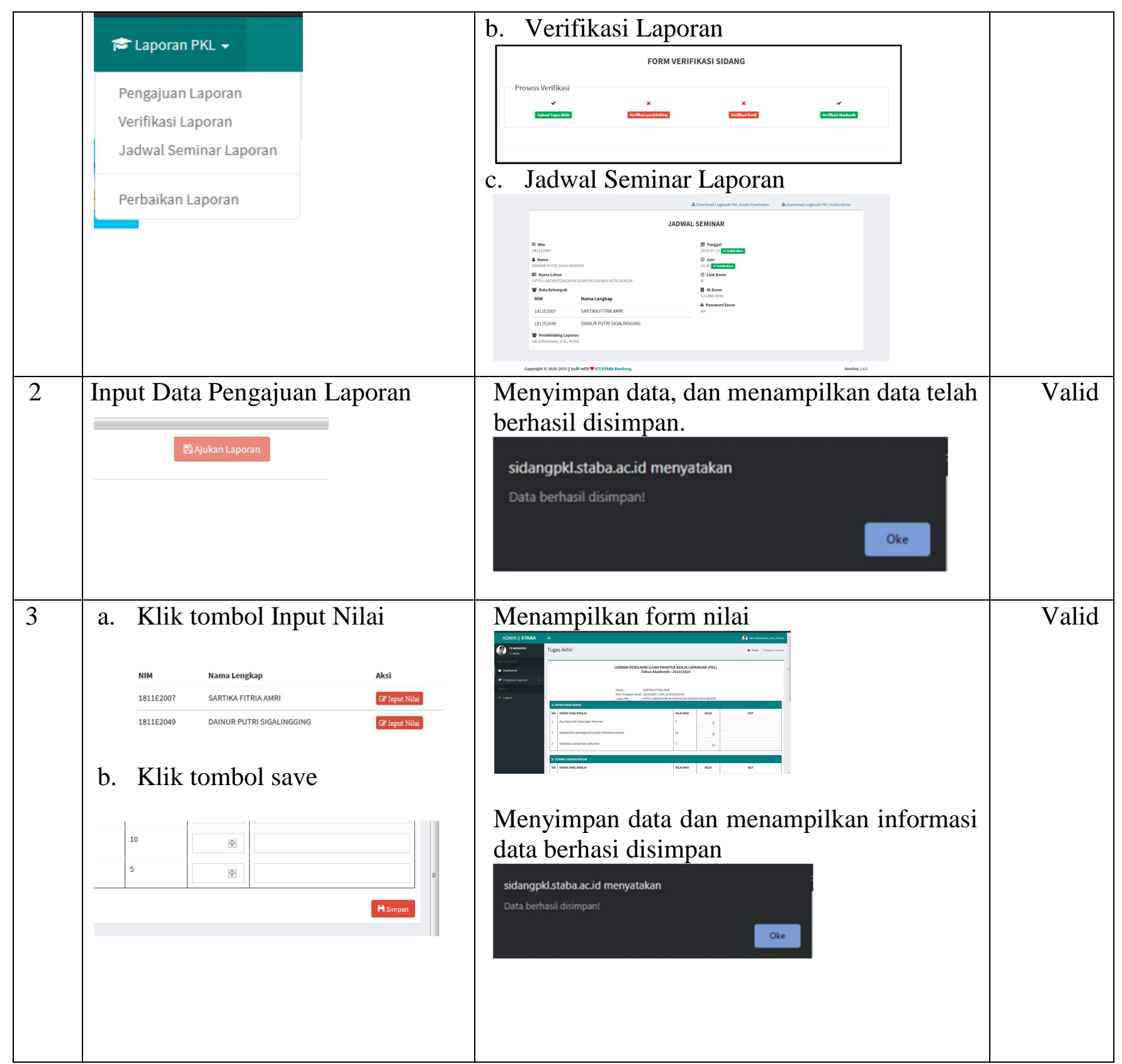

\section{Kesimpulan}

Adapun kesimpulan pada penelitian ini adalah sebagai berikut :

a. Sistem pengajuan sidang laporan PKL mahasiswa Sekolah Tinggi Analis Bakti Asih yang sedang berjalan kurang efektif dan efisien yang mengakibatkan terjadinya beberepa kendala.

b. Sistem usuluan pengajuan sidang laporan PKL mahasiswa Sekolah Tinggi Analis Bakti Asih dapat menjad solusi untuk mengatasi kendala-kendala yang terjadi pada sistem yang berjalan.

c. Aplikasi pengajuan sidang laporan PKL dapat dengan mudah digunakan oleh pihak Sekolah Tinggi Analis Bakti Asih untuk mengelola sidang laporan PKL mahasiswa. 


\section{Daftar Pustaka}

[1] A.S. Moenir, (2010). Manajemen Pelayanan Umum Di Indonesia. Bumi Aksara : Jakarta.

[2] Bekti, Humaira. (2015. Dreamweaver CS6, CSS dan Jquery. Yogyakarta: ANDI OFFSET

[3] Erlina Setiyorini, Setiyorini. (2017). Web media dakwah: studi deskriptif situs resmi PCNU Kota Surabaya. Undergraduate thesis, UIN Sunan Ampel Surabaya.

[4] Sujatmiko, Eko. (2012). Kamus Teknologi Informasi dan Komunikasi. Surakarta: AKSARRA SINERGI MEDIA

[5] Syukroni, Muh Farhan. (2017). Rancang Bangun Knowledge Management System Berbasis Web Pada Madrasah Mualimin Al-Islamiyah Uteran Geger Madiun. Skripsi thesis, Universitas Muhammadiyah Ponorogo. 